\title{
TO BRIBE OR TO CHEAT? EFFECTS OF SELF-MONITORING AND GENDER
}

\author{
SUBORNAR OU ENGANAR? EFEITOS DO AUTOMONITORAMENTO E GÊNERO
}

Recebido em 09.04.2021 Aprovado em 26.06.2021

Avaliado pelo sistema double blind revien DOI: https://doi.org/10.12712/rpca.v15i2.49628

\author{
Ana Carla Bon \\ anacarla.bon@hotmail.com \\ IAG/Pontifícia Universidade Católica do Rio de Janeiro, Rio de Janeiro, RJ, Brasil \\ https://orcid.org/0000-0002-8108-2700
}

\begin{abstract}
This study aimed to contribute to business ethics research investigating the effects of two individual differences - self-monitoring personality and gender - on ethical decision making. Applying a bribery scenario (intentions) and a cheating matrix task (behavior), results showed that high self-monitors had more unethical intention and behavior than low self-monitors. Moreover, low self-monitors had more consistency intention-behavior than high self-monitors, and the inconsistencies of the later were different regarding gender. The bi-dimension of self-monitoring construct - acquisitive and protective - was tested and brought additional evidence about the ones who bribes. Possible explanations of these findings are discussed, with suggestions for future research.
\end{abstract}

Keywords: Self-monitoring. Gender. Inconsistency intention-behavior. Ethical decision.

\section{Resumo}

Este estudo investigou os efeitos de duas diferenças individuais - automonitoramento e gênero - na tomada de decisão ética. Aplicando um cenário de suborno (intenções) e uma tarefa de matriz de burla (comportamento), os resultados mostraram que indivíduos com automonitoramento em níveis altos tinham mais intenção e comportamento antiético do que aqueles com automonitoramento baixo. Além disso, aqueles com automonitoramento mais baixos apresentaram comportamentos mais consistentes com suas intenções do que os indivíduos com automonitoramento altos, sendo as inconsistências dos últimos diferentes em relação ao gênero. Duas dimensões do construto automonitoramento - aquisitivo e protetor - foram analisadas e trouxeram evidências adicionais sobre quem suborna.

Palavras-chave: Automonitoramento. Gênero. Inconsistência intenção-comportamento. Decisão ética. 


\section{Introduction}

There is a consensus in the literature that individual traits affect ethical decision-making. Individual variables used in empirical research based on Rest's (1986) model for Individual Ethical Decision-making (based on a four-step model of awareness, judgment, intention, and behavior) and Jones' (1991) IssueContingent Model were discussed in consecutive literature reviews (Craft, 2013; Kish-Gephart, Harrison, \& Treviño, 2010; O'Fallon and Butterfield, 2005).

Moreover, Kish-Gephart et al. (2010), in their seminal meta-analyses which coined the expression "bad apples, bad barrels, bad cases", contributed to understand of the simultaneous effect of individual factors, situational and moral intensity on ethical decision-making and confirmed that, the three most studied individual variables - CMD (moral development), Machiavellianism, and locus of control - contributed to unethical intention and unethical behavior.

Self-monitoring is a stable dispositional individual characteristic (Snyder, 1974) which can be expressed as "the individual differences in the propensity for impression management involving the construction of positive social appearances," in order to influence evaluations of oneself and to win approval from others (Day, Schleicher, Unckless, \& Hiller, 2002, p. 390; Gangestad \& Snyder, 2000). Wilmot, De Young, Stillwell and Kosinski (2016, p. 336) found that a bi-dimensionality of self-monitoring were related to two metatraits (also called high order factors) which are "the substantive traits that accounts for much of the variance among the Big Five or Five Factor Model". Acquisitive self-monitoring was strongly and positively related to the metatrait Plasticity or Engagement (which is associated to reward seeking, accomplishment of ambitious goals and exploration of information) whereas protective selfmonitoring had a moderate and negative relation to the metatrait Stability or Self-control, (which is related to Emotional Stability, Conscientiousness and Agreeableness).

The self-monitoring personality is very relevant to business research and there is an extensive literature about it (Day and Schleicher, 2006; Day, Schleicher, Unckless, \& Hiller, 2002; Kudret, Erdogan, Bauer, 2019), mainly its positive side, in different areas such as performance (Flynn \& Ames, 2006), leadership (Türetgen, Unsal, \& Dural, 2017), social network and career (Oh \& Kilduff, 2008). However, researchers also found that self-monitoring affects unethical decision-making (Bon, Volkema \& Silva, 2017; Ogunfowora, Bourdage \& Nguyen, 2013; Yang, Yu \& Huang, 2019), and is related to other questionable behaviors at work (Bolino, Klotz, Turnley, \& Harvey, 2013; Jawahar, 2001; Oh, Charlier, Mount, \& Berry, 2014).

Moreover, some scholars found relevant differences when applying an interactive perspective of selfmonitoring (or impression management, which is a key characteristics of this personality trait) and gender on different areas, such as social-network structure and career (Bon, Moraes \& Silva, 2018), response to advertising (Lammers, 1991), performance evaluation (Barsness, Diekmann and Siedel, 2005), and selfdisclosure behaviors (Shaffer \& Pegalis, 1998).

Therefore, the purpose of this study is to explain the combined role of gender and self-monitoring on ethical intentions and behaviors and the consistency between both. Applying a multi-method - a business scenario of bribery followed by a cheating task - to measure unethical intention and behavior, respectively, of professionals in different management positions this study aimed to contribute to research in business ethics, considering that high self-monitors are more likely to be at high hierarchical positions in organizations and create the "glass ceiling" effect against women (Day and Schleicher, 2006), and ethical leadership can affect the performance of the whole organization team (Treviño, L. K., Hartman, L. \& Brown, 2000; Badrinarayanan, Ramachandran, \& Madhavaram, 2019). 


\section{Theoretical Position and Hypotheses}

The theory of self-monitoring (Gangestad and Snyder, 2000, p. 530) suggests that people differ "meaningfully in the extent to which they can and do engage in expressive control." That is, people differ in the extent to which they value, create, cultivate and project social images and public appearances. High self-monitors have the propensity to perceive social cues and adapt their behaviors to impress others. On the other hand, low self-monitors do not adapt to the situation: instead their "expressive behavior functionally reflects their own inner attitudes, emotions, and dispositions". Moreover, high self-monitors cultivate public images of social status and, therefore, construct social worlds that can function as instruments of status enhancement, whereas low self-monitors construct social networks that support their reputation as sincere people, and are also related to modesty, humility and humbleness.

Considering ethical decision-making, high self-monitors can be more susceptible to unethical influences of their social environments (Day \& Schleicher, 2006; Pinto, Leana, \& Pil, 2008), and are more likely to unethical decision-making (Bon, Volkema \& Silva, 2017), to act unethically in business decision-making by engaging in moral disengagement (Ogunfowora, Bourdage \& Nguyen, 2013) and to have more opportunistic and unethical selling behavior against customers (Yang, Yu \& Huang, 2019). Indeed, literature supports the negative side of the high self-monitors personality at work in a variety of work situations (e.g., Bolino et al., 2013; Hogue, Levashina, \& Hang, 2013; Hewlin, 2003; Oh et al, 2014; Caldwell \& O’Reilly III, 1982).

Moreover, high self-monitors were related to lower honesty-humility (Ashton \& Lee, 2005), and to correlate to the Dark Triad, which are "the three socially malevolent personality traits narcissism, Machiavellianism and psyhcophaty" (Kowalski, Roogoza, Vernon \& Schermer, 2018, p. 234) and all these personality traits were related to unethical decision in previous research (e.g. Brown et al., 2010; Gürlek, 2020). Therefore, this study suggests that,

H1: An individual's self-monitoring will be related to unethical intentions.

H2: An individual's self-monitoring will be related to unethical behavior.

Regarding gender, some scholars noticed that studies on ethical decision have been "characterized as atheoretical" (Lee, Pitesa, Pilluta \& Thau, 2017, p. 2017), and indeed "experimental studies on dishonesty rarely refer to theoretical reasons for gender differences” (Gerlach, Teodoreacu, \& Hertwig, 2019, p.4). However, researches apply different perspectives to argue that women tend to be more ethical than men : a) social role theory (Eagly, 1987), arguing that women are expected to be communal and expansive, whereas men are more agentic and instrumental; b) ethics of care theory, based on argumentation that women has a moral orientation of care and relationship whereas men has a logic and individualistic orientation (Gilligan, 1982) (for a review see, Jaffe \& Hyde, 2000); c) gender identity theory (Spence, 1973), suggesting that gender is a multifactorial construct consisting of biological sex, instrumental versus expressive traits, and gender-role attitudes (e.g. McCabe, Ingram \& Daton-on, 2006); and d) parental investment theory (Trivers, 1972), based on mating motiv;ation would lead to more unethical behavior of males ( Lee et al., 2017). Although there is not a consensus in the literature about the effects of gender on ethicality, and gender-ethics relation is complex (e.g, Berings \& Adrianenssens,2011), two broad metaanalysis found that women are slightly more ethical (intention and behavior) than men: Kish-Gepart et at. (2010) (but usually in a weak significance when analysed together with other factors), and Gerlach et al. (2019, p. 14) reviewing experiments studies on cheating and other unethical behaviors. Therefore, this study proposes that

H3: Men will be more related to unethical intentions than women

H4: Men will be more related to unethical behaviors than women 
The issue-contingent model of ethical decision-making (Jones, 1991) proposes that unethical intention, the level of the moral issue, as well as individual and situational factors can predict unethical behavior. Self-monitoring is an individual factor which is associated with adaptive behavior. Low self-monitors do not adapt their behavior relative to others in their relationship (Snyder, 1987); their behavior is overt, predicted by intentions (Ajzen, Timko, \& White, 1982; Prislin \& Kovrlija, 1992; Snyder \& Kendzierski, 1982). In contrast, high self-monitors are sensitive to situational demands, so they could have a higher propensity to deviate from previously formed intentions (Ajzen et al., 1982).

More specific to self-monitoring, Snyder and Kendzierski (1982) investigated the relationship of attitudes to behaviors, offering individuals the opportunity to choose whether to enter into situations that require them to undertake actions implied by their attitudes. Low self-monitors chose to engage in attitudecongruent situations while avoiding attitude-incongruent situations (i.e., they chose to enter situations that supported the behavioral expression of attitudes favourable to affirmative actions); for high selfmonitors, there was no relationship between personal attitudes and choice in these situations.

Ajzen's $(1985,1988)$ theory of planned behavior contends that behavior is not a function of intentions alone, but that perceived behavioral control also explains behavior. As defined by Ajzen and Madden (1986, p.457) perceived behavioral control is "the person's belief as to how easy or difficult performance of the behavior is likely to be". Prislin and Kovrlija (1992,1131), complemented Ajzen's study and showed that high self-monitors' behaviors were predicted by the interaction of intention to perceived behavioral control. That is, high self-monitors' behaviors are a function of their intention (which is formed based on relevant others' opinions) and the perceived availability of resources and opportunity to perform the behavior (that is, "they will translate intention into behavior only if he does not perceive serious obstacle to it"). They explain that "perception of control is based not only on estimation of one's abilities to perform a behavior but also on the perception of situational opportunities (facilitators and inhibitors) for the behaviors as well."

In subsequent studies, high self-monitors were found to manifest a weaker relationship between turnover intentions and the turnover act (Allen, Weeks \& Moffitt, 2005), to moderate the relationship between attitudes toward accurate appraisal and the rating (and were also more lenient and inaccurate in performance rating and decision making)(Jawahar, 2001), to have lower behavioral integrity (i.e., inconsistencies between promises and actions) (Simons, 2002), and to be more susceptible to the behavioral characteristics associate with social roles (Adams \& Tyler, 2018). In addition, an individual's attitude strength (temporal stability) and ambivalence explain part of the intention-behavior variance (Cooke and Sheeron, 2004).

Moreover, Snyder and Kendzierski (1982) found that females who are high self-monitors are more willing than males high self-monitors, to choose to enter social situations that support the behavioral expressions of their attitudes. As for low self-monitors, gender is not significant when choosing social situations. While these findings were not only specific to ethical decision-making, they suggest the following hypothesis:

H5: Low self-monitors will present higher ethical intention-behavior consistency than high selfmonitors.

H6: Gender will not be related to Low self-monitors intention-behavior consistency, but will be related to high self-monitors consistency.

Moreover, Wilmot et al. (2016) reviewed previous research (Young et al., 2002) that found that Stability was positively and Plasticity was negatively related to conform to social norms, and therefore people with high protective self-monitoring (low stability) and high acquisitive self-monitors (high plasticity that could lead to win at all cost) could have no conformity to social norms. On the other side, the "behavioral 
inconsistency and identity confusion of low Stability personalities" (Wilmot, 2019, p.337) could explain the inconsistent intention-behavior of high protective self-monitors.

H7: Individuals who have high acquisitive self-monitoring and high protective self-monitoring are related to unethical intention and unethical behavior.

H8: Individuals who have high protective self-monitoring are related to inconsistency intention-behavior.

\section{Method}

This study was based on an on-line survey to collected self-monitoring data, one ethical decision scenario (ethical intention), followed by a web-based task (ethical behavior).

\section{Sample}

This study collected 129 valid surveys and task from professionals. The sample was well balanced in terms of gender ( 70 males and 59 females), and hierarchy ( 24 not supervisors, 18 supervisors, 54 managers, 27 directors (senior managers), and 6 VPs). Self-monitoring, applying the median value, had the following distribution: 60 were low self-monitors (32 males and 28 females) and 69 were high selfmonitors (38 males and 31 females).

\section{Self-monitoring}

This study used the 25-item self-monitoring instrument employed by Snyder (1987), and for each statement, participants were asked to respond using a 5-point Likert scale, from strongly disagree to strongly agree. The Cronbach alpha for this instrument was 0.78 , in line with other studies (e.g., Day et al., 2002). Self-monitoring was used in its dichotomized form consistent with past research (Bolino and Turnley, 2003), which used the median to classify the respondents as high or low self-monitors. For additional analysis the variables acquisitive self-monitoring and protective self-monitoring were applied, based on two sub-scales of the self-monitoring scale $(\mathrm{KMO}=0.67$, Bartlet sig <0.001; all MSAs $>0.45$ ) as defined by Wilmot et al. (2016).

\section{Ethical intentions}

To measure ethical intentions a scenario, which presents a decision to be made regarding the engagement with a partner who uses bribery, was borrowed and adapted from previous studies (Glover, Bumpus, Logan, \& Ciesla,1997; Bon, Volkema \& Silva,2017): "The respondent had four options to answer (definitely not, probably not, probably yes, definitely yes) to the scenario: You are working on a sale of equipment produced by your company ZMT to a major international customer. This sale is particularly important for you and for the company because ZMT is currently experiencing very critical difficulties. You have been suggested to work on the sale together with a company that is part of your company's partner alliance. This morning, however, you received information that this partner, who is the key liaison with the customer, has committed, with no written agreement, a series of payments to various people in order to secure the contract. These people range from intermediaries to buyer representatives of the government customer. You and your company will not be involved directly in these payments. This contract is crucial to ZMT, as it can avoid layoffs (including part of your team) and secure a better position against competition. Would work with this partner?”

\section{Ethical behavior - a task}

To measure ethical behavior, the numbers matrix task proposed by Mazar, Amir, and Ariely (2008) was adapted. The task, which tests whether individuals will lie, even "just a little bit," has been used in a 
number of recent ethical decision-making studies (see Gerlach et al. (2019) for a review of 27 articles which applied the cheating matrix task). Following Wiltermuth's (2011) adaptation for an on-line implementation of the task, this study presented participants with a single screen of 12 matrices, each containing 10 three-digit numbers (e.g., 1.67). For each matrix, participants were told that they should find two numbers that summed to ten. They were also instructed that they could solve the matrices in any order and that they had till three minutes to complete the task. The participants were not asked to circle the numbers whose sum is 10 , but merely to check the box "found it" which appears below each matrix. As Wiltermuth explained, "as such, participants were led to believe that the experimenter could not check whether they actually solved each matrix that they indicated solving. Participants, however, did not know that some of the matrices did not contain number pairs that added to 10" (p. 163). This study did not gave any incentives, takin into consideration the conclusions of other studies that offering incentives can be counterproductive (O’Neil and Penrod, 2001; Gneezy and Rustichini, 2000; Kamenica, 2012). Cheating was measured by the number of invalid matrix checked.

\section{Results}

Twenty-four respondents (18.6\%) answered "definitely yes" or "probably yes" to the bribery scenario. Self-monitoring correlates significantly and positively to bribery $(0.28, \mathrm{p}<.01)$, and an ANOVA $(\mathrm{F}=$ 6.18, $\mathrm{p}<.01)$ confirmed that high-self-monitor was related to unethical intention, supporting H1. Considering gender, there was no difference related to unethical intention, and $\mathrm{H} 3$ was not supported. However, there were differences regarding the break-down by self-monitoring: among the high selfmonitors, males $(22.8 \%)$ were more unethical than females $(13.5 \%)$, ANOVA $(\mathrm{F}=5.11, \mathrm{p}<.05)$. Table 1 presents the correlations among the variables

Table 1. Descriptive Statistics and Correlation Matrix for Primary Variables a

\begin{tabular}{|c|c|c|c|c|c|c|c|c|}
\hline Variable & Mean & SD & & 1 & 2 & 3 & 4 & 5 \\
\hline \multicolumn{9}{|l|}{ Individual Factors } \\
\hline 1. Gender ${ }^{\mathrm{b}}$ & 0.46 & \multicolumn{2}{|l|}{.50} & & & & & \\
\hline 2. Self-monitoring & 2.81 & \multicolumn{2}{|c|}{.42} & -.05 & \multirow{3}{*}{\multicolumn{2}{|c|}{$.21 *$}} & & \\
\hline 3. Acquisitive Sm & 2.88 & .63 & .18 & $.80^{* * *}$ & & & & \\
\hline 4. Protective Sm & 2.55 & .53 & -.11 & $.63^{* *}$ & & & & \\
\hline \multicolumn{9}{|c|}{ Unethical Intentions (Scenario) } \\
\hline 5. Bribery & 1.70 & .79 & & -.10 & $.28^{* * *}$ & $.16^{\dagger}$ & $.22^{*}$ & \\
\hline \multicolumn{9}{|c|}{ Unethical Behavior (Task) } \\
\hline 6. Matrix errors & 0.50 & .87 & & $.32^{* * *}$ & $.16^{\dagger}$ & $.15^{\dagger}$ & .06 & .11 \\
\hline \multicolumn{9}{|c|}{ Consistency Intention to Behavior } \\
\hline 7. Consistency & 0.67 & .047 & $-.18^{*}$ & & $4^{* *}-.14$ & $-.22^{*}$ & $-.21^{*}$ & $-.51^{* * *}$ \\
\hline
\end{tabular}

${ }^{a} \mathrm{~N}=129{ }^{\dagger} \mathrm{p}<.10,{ }^{*} \mathrm{p}<.05,{ }^{* *} \mathrm{p}<.01,{ }^{* * *} \mathrm{p}<.001$

b Male $=0$, Female $=1$

Considering the task results, $40(31.0 \%)$ respondents checked at least one invalid matrix. Cheating correlates to gender $(0.32, \mathrm{p}<.00)$ and weakly to self-monitoring $(0.19, \mathrm{p}<.10)$, and an ANOVA $(\mathrm{F}=4.9, \mathrm{p}<.05)$ confirmed that high self-monitors also had higher unethical behavior than low selfmonitors and $\mathrm{H} 2$ was supported. However, when considering gender, contrary to what was expected (Gerlach et al., 2019), females had a higher percentage of checking an invalid matrix than did men, 
ANOVA test confirmed this result $(\mathrm{F}=14.43 ; \mathrm{p}<.00)$. Therefore $\mathrm{H} 4$ was not supported, indeed was the contrary.

With respect to the relationship between intentions and behavior, a consistency dichotomic variable was defined which values one if the respondent had the following result: a) ethical intention and ethical behavior or b) unethical intention and unethical behavior; or value zero otherwise. Consistency correlates negatively to self-monitoring $(-0.23, \mathrm{p}<.01)$ and, in accordance to previous research (Ajzen et al., 1982; Prislin et Kovrlija, 1992), low self-monitors (78.3\%) presented higher consistency of their intentionbehavior than high self-monitors $(56.5 \%)$, ANOVA $(\mathrm{F}=7.15, \mathrm{p}<.00)$, supporting H5.

In addition, in line with Snyder \& Kendziski (1982) findings, the low self-monitors consistency was not related to gender (low self-monitors males $=84 \%$ consistency; low self-monitors females $=71.4 \%$ consistency). Low self-monitors behaviors were related directly to their intentions: they correlated $(0.36$, $\mathrm{p}<.00)$ and $\operatorname{ANOVA}(\mathrm{F}=11.30, \mathrm{p}<.00)$. For high self-monitors, behavior could not be predict by intention (no significant ANOVA) and there was an unexpected difference between the consistency of high self-monitors regarding gender, as the direction of ethicality intention-behavior changed: females had more inconsistency due to higher unethical behaviors compared to their ethical intentions, whereas males reduced their unethical behaviors compared to their unethical intention. Moreover, high selfmonitors females $(45.2 \%)$ had lower consistency than high self-monitors males $(65.8 \%)$, therefore, H6 was partially supported. Table 2 summarizes consistency results.

Table 2. Consistency Intention-Behavior (Bribery-Cheating) by Self-monitoring and Gender

\begin{tabular}{|c|c|c|}
\hline Consistency & \multicolumn{2}{|c|}{ Self-monitors } \\
\hline Intention-Behavior & Low & High \\
\hline Males & $84.4 \%$ & $65.8 \%$ \\
\hline Females & $71.4 \%$ & $45.2 \%$ \\
\hline Total & $78.3 \%$ & $56.5 \%$ \\
\hline
\end{tabular}

Considering Willmot et al. (2019) suggestion that the unitary function of the self-monitoring bidimension would affect intention and behavior, a Discriminant analysis was used to identify the relation of acquisitive self-monitoring and protective self-monitoring to bribery(intention), cheating (behavior) and the consistency intention-behavior. The sample means for acquisitive self-monitoring was 2.88 $(\mathrm{Std}=0.63)$ and protective self-monitoring was $2.55(\mathrm{Std}=0.53)$, and there was no difference considering gender. The group related to unethical intention (bribery) presented high acquisitive self-monitoring (therefore high plasticity) and high protective self-monitoring (and therefore low stability and conscientiousness): acquisitive self-monitoring $=3.15$, Std $=0.71$; protective self-monitoring $=2.77$, Std $=0.63$; tests of equality of group means were significant at $\mathrm{p}<.05$; Box's $\mathrm{M}$ test not significant; Wilk's Lambda significant at $\mathrm{p}<.01$; standardized canonical acquisitive $=0.68$ and protective $=0.62$ ). However, discriminant analysis had no significant results for Cheating or consistency intention-behavior.

In order to shed some light on whether perceived behavior control (pbc) of the situation could explain behavior inconsistency to intentions, this study conducted a test using item 20 of the self-monitoring scale as its proxy: "I have never been good at games like charades or improvisational acting" (which is a reversed item in the survey, and therefore lower scores are related to low self-monitoring). Therefore, people who were able to identify that there was a "trick situation" in the cheating matrix task, could avoid "unethical behavior" to mark many matrices without solutions.

There was no difference in pbc between males and females, but there was a high and significant difference between low and high self-monitors $(\mathrm{F}=11.02, \mathrm{p}<.00)$, Although low self-monitors (males $=2.88, \mathrm{SD}$ $=1.08)$ had a lower PBC than high self-monitors $(3.49, \mathrm{SD}=1.08)$ this did not affect the relationship 
intention-behavior in line Prislin and Kovrlija (1992, p. 1138) who explanation that "a low self-monitor does what he intends to do that depends on how he feel".

However, once more there was an effect of gender and self-monitoring as perceived behavioral control had a difference (although in a weak significance), among high self-monitors males $(3.71, \mathrm{SD}=0.84)$ and high self-monitors females $(3.23, \mathrm{SD}=1.10)$, ANOVA $(\mathrm{F}=4.12 ; \mathrm{p}<.10)$. Therefore, this is a possible explanation why high self-monitor males (who had the highest score by far for bribery) had less unethical behavior, compared to their unethical intention. As an example, one male respondent gave the following feedback about the matrix task, "I need to admit that I was checking off many of the matrices, but then I thought, there is something tricky about this, and then I decided to do the right thing."

\section{Discussion}

This study proposed to investigate the effects of two individual factors - self-monitoring personality and gender - on ethical decision making, considering intentions (a bribery scenario) and behavior (a cheating matrix task), as well as the consistency among both. In summary, high self-monitors had more unethical intention and behavior than low self-monitors. It also brought additional evidence that the ones related to bribery were high in both acquisitive and protective self-monitoring, in accordance to the suggestion of Wilmot et al. (2016) about the power of the bi-dimensionality of self-monitoring construct in explaining the lack of conformity to social norms (win-to-all costs and adapt to situation).

Considering gender only, there was no difference in ethical intentions. However, among the high selfmonitors, males were the ones who chose more to work with a partner that bribes to win business contract. However, contrary to what might be expected (Gerlach et al., 2019), a higher percentage of females than males checked invalid matrices, and high self-monitor women had the highest rate of such unethical behavior.

In line with self-monitoring theory (Gangestad and Snyder, 2000), which posits that low self-monitors do not adapt their behaviors, and previous empirical researches, low self-monitors behavior were predicted by their intentions, i.e., they had more consistency in intention-behavior (Adams \& Tyler, 2018; Ajzen, Timko, \& White, 1982; Snyder \& Kendzierski, 1982). Important to notice that it does not mean that they are always ethical, but they are consistent between their intentions and behavior. Besides, the low self-monitors consistency were not related to gender (Snyder \& Kendziski, 1982), whereas high selfmonitors had inconsistency intention-behavior. Further, there was an unexpected increase in unethical behavior (cheating) by high self-monitors females (compared to their ethical intentions), and on the opposite direction, there was an unexpected effect of lower unethical behavior of high self-monitors males (compared to their unethical intentions), which could be partially explained by the theory of planned behavior (Ajzen's,1985, 1988), as the higher perceived behavioral control (in this case, to understand the trick of the situation in the task) of the later.

Moreover, the self-monitoring theory can help explain the lack of consensus in the literature about the effects of gender on ethicality (e.g, Berings \& Adrianenssens,2011). One first possible explanation for unethical behavior of females, and even more of high self-monitors females, comes from Dalton and Ortegren (2011), who found that females exhibit more social desirability than do males in research on ethics. However, self-monitoring is a construct that can explain social bias. As McGrath, Mitchell, Kim \& Hough (2010) found impression management (an intrinsic characteristic of self-monitors) is one important source of response bias. Therefore, the explanation of social bias could be even stronger considering the self-monitoring personality of females when answering the ethical scenarios, i.e., the high self-monitors females who cheated checking invalid matrix could potentially be less ethical as they want to appear in their ethical intention scenarios (probably not to be considered having inappropriate choices based on the female stereotype as can be explained by the social role theory (Eagly, 1987)). Indeed, females were found to choose more ethical answers when the questions are formulated in a more abstract way (e.g., to get an unfair advantage) than when more practical cases are presented (Berings \& 
Adriaenssens, 2011). It is worth noting that previous studies using matrix task found that cheating in the lab, predicted real fraud in the field (e.g., Dai, Galeotti \& Villeval, 2018).

Another explanation could come from Kish-Gephart et al. (2010), who suggested that an impulsive act could explain the difference between intentions and behavior, leading to a less deliberative approach to ethical decision-making (in the case of the matrix task, it would be the time pressure of task completion). For example, as Gino, Schweitzer, Mead \& Ariely (2011) found, people in high depletion conditions can reduce their self-control and self-regulation and act more unethically (but not the individuals who presented high moral identity), and time pressure could arise different effects, considering gender, on behavior (De Paola \& Gioia, 2016; Schurchkov, 2012). Other researchers (e.g.; Saquid and Chen, 2015) also found that time pressures could even reverses risk preferences and, therefore, inconsistent high selfmonitors females, which seemed to be more avert to risk (as they had a low unethical intention in the bribery scenario which is risky), could have increased their risk preferences, in light of time pressure.

\section{Limitations and Future Research}

As any other research, this study has some limitations. First, the cheating task in this study was not an experiment applying a control group regarding incentives to cheat. However, Covey, Saladin \& Killen (1999) also found that high self-monitors were more likely to cheat when no incentive were offered and the authors argued that this could be due to high self-monitors motivation to present a favourable image of self (capable to find the solutions); on the other hand when monetary incentives were offered, high self-monitors were no more likely to cheat than low self-monitors.

In addition, the object of intention (bribery scenario) and behavior (cheating task) are different, and therefore should cautious the conclusions about the consistency intention-behavior. However, it is quite difficult (if not impossible) to measure real bribery behavior, and therefore the use of cheating as a behavior could support some comparisons of unethical acts.

Moreover, although this sample can be considered relatively small, it is worth noting that in the metaanalysis of 565 experiments on dishonesty (101 studies using the matrix cheating task in different situations), Gerlach et al. (2019, p. 6) discussed that "most experiments had relatively small samples and $77 \%$ were college or universities students (most of them in theirs 20's ) and another percentage were from pools "survey"s professionals". Therefore, this study contributes to understand unethical behavior of professionals, most of them in high level hierarchical positions and, in an appropriate balance of selfmonitoring and gender, enriching research in the field of ethical decision.

In addition, the possibility that the moral issue intensity (Jones' (1991) Issue-Contingent Model), could affect differently females and males should not be disregarded, as the percentage women deciding for bribes (bribery scenario) was substantially less than cheating. That is, to "lie" a little bit about finding a sum of two numbers is quite different from the moral intensity represented by a bribery scenario. Therefore, future studies might consider the benefits of including qualitative methods, which might be useful in providing insights to findings like females' unexpected frequency of choosing the invalid matrix option.

Future research, could further explore self-monitoring and gender interaction in an experimental design, to investigate whether a higher perceived behavior control based on the theory of planned behavior (Ajzen's,1985, 1988), or social roles (to show expertise in solutions) could have affected high selfmonitors behavior. Indeed, social roles was also found to have effects on behaviors of high self-monitor (Adam \& Tyler, 2018) and Wiltermuth (2011) found that women cheated more in a word-jumble experiment than men in the case that one friend would benefit from the number of solutions solved. 


\section{Final Comments}

This study contributed to ethical decision-making research and self-monitoring research, reinforcing the importance to investigate the self-monitoring personality at work and its impact to organization ethics, not only regarding gender differences, but also the trustworthiness of low self-monitors presented in their "walk the talk" consistency.

Moreover, brings an important contribution to the evolution of self-monitoring theory as it brought evidence that the construct bi-dimension - acquisitive and protective can fruitfully apply the extensive knowledge already available at the Big-Five framework to further understand self-monitors social behavior.

More than ever urges, that researchers focus on ethical leadership who will be able to challenge traditional approaches to do business and have a more ethical and systemic view of business, social, and environmental demands.

\section{References}

Adams, K. E., \& Tyler, J. M. (2018). High self-monitors moderate their responses as a function of relevant social roles. European Journal of Social Psychology, 48, 150-158. Doi: 10.1002/ejsp.2312

Ajzen, I. (1991). The theory of planned behavior. Organizational Behavior and Human Decision Process, 50(2), 179-211. doi: 10.1016/0749-5978(91)90020-T

Ajzen, I., \& Fishbein, M. (1980). Understanding attitudes and predicting social behavior. Englewood Cliffs, NJ: Prentice-Hall.

Ajzen, I., \& Madden, T. J. (1986). Prediction of goal directed behavior: Attitude, Intentions and perceived behavior control. Journal of Experimental Social Psychology, 42, 426-435. Doi: 10.1016/0022-1031(86)90045-4

Ajzen, I., Timko, C., \& White, J. B. (1982). Self-monitoring and the attitude-behavior relation. Journal of Personality and Social Psychology, 42, 426-435. doi:10.1037/0022-3514.42.3.426

Allen, D. J., Weeks, K. P. \& Moffitt, K. R. (2005). Turnover intentions and voluntary turnover. The moderating roles of self-monitoring, locus of control, proactive personality, and risk aversion. Journal of Applied Psychology, 90, 980-990. doi: 10.1037/0021-9010.90.5.980

Ashton, M. C., \& Lee, K. (2005). Honesty-humility, the Big-Five, and the five-factor model. Journal of Personality, 73(5), 1321-1353. doi: 10.1111/j.14676494.2005.00351.x

Badrinarayanan, V., Ramachandran, I., \& Madhavaran, S. (2019). Mirroring the boss: Ethical Leadership, emulation intention, and salesperson performance. Journal of Business Ethics, 159, 897-912. doi: 10.1007/s10551-018-3842-1

Berings, D., \& Adrianenssens, S. (2011). The role of business ethics, personality, work values and gender in vocational interests from adolescents. Journal of Business Ethics, 106, 325-335. 10.1007/s10551-011-0999-2

Bolino, M. C., \& Turnley, W. H. (2003). More than one way to make impression: Exploring profiles of impression management. Journal of Management, 29, 141-160. doi: 10.1016/S0149-2063(02)00212-X

Bolino, M. C., Klotz, A. C., Turnley, W. H., \& Harvey, J. (2013). Exploring the dark side of organizational citizenship behavior. Journal of Organizational Behavior, 34(4), 542-559. doi: 10.1002/job.1847.

Bon, A. C., Moraes, S. T. A., \& Silva, J. F. (2018). The Influence of social network and self-monitoring on career. Revista. Adm. FACES Journal, 17(1), 70-88. doi: 10.21714/1984-6975FACES2018V17N1ART5041

Bon, A. C., Volkema, R., \& Silva, J. F. (2017). Ethical decision-making: The role of self-monitoring, future orientation and social network. Brazilian Administration Review, 14, 1-19. 10.1590/1807-7692bar2017160091

Brown, T. A., Sautter, J. A., Littvay, L., Sautter, A. c.; \& Beaurnes, B. (2010). Ethics and Personality: Empathy and narcissism as moderator of ethical decision-making in business students. Journal of Education in Business, 85, 203-208. doi: 1080/08832320903449501 
Caldwell, D. F., \& O’Reilly III, C. A. (1982). Responses to failure: The effects of choice and responsibility on impression management. Academy of Management Journal, 25, 121-136. doi: 10.2307/256028

Chen, J., Tang, T. L.,\& Tang, N. (2014). Temptation, monetary intelligence (love of money) and environmental context on unethical intentions and cheating. Journal of Business Ethics, 123, 197-219. doi: 10.1007/s10551-013-1783-2

Cooke, R., \& Sheeran, P. (2004). Moderation of cognition-intention and cognition-behavior relations: A metaanalysis of properties of variables from the theory of planned behavior. British Journal of Social Psychology, 43, 159-186. doi: 10.1348/0144666041501688

Covey, M. K.; Saladin, S.; \& Killen, P. J. (1999). Self-monitoring, surveillance, and incentives effects on cheating. The Journal of Social Psychology, 129(5), 673-679. doi: 10.1080/00224545.1989.9713784

Craft, J. L. (2013). A review of empirical ethical decision-making literature: 2004-2011. Journal of Business Ethics, 117(2), 221-259, doi: 10.1007/s10551-012-1518-9.

Dai, Z., Galeotti, F., \& Villeval, M. C. (2018). Cheating in the lab predicts fraud in the field: An experiment in public transportation. Management Science, 64, 1081-1100. Doi: 10.1287/mnsc.2016.2616f

Dalton, D., \& Ortegren, M. (2011). Gender differences in ethics research: The importance of controlling for the social desirability response bias. Journal of Business Ethics, 103, 73-93. doi: 10.1007/s10551-011-0843-8

Day, D. V., Schleicher, D. J., Unckless, A. L., \& Hiller, N. J. (2002). Self-monitoring personality at work: A meta-analytic investigation of construct validity. Journal of Applied Psychology, 87(2), 390-401. doi: 10.1037//0021-9010.87.2.390

Day, D. V., \& Schleicher, D. J. (2006). A motive based perspective. Journal of Personality, 74(3), 685-714. doi: $10.1111 / \mathrm{j} .1467-6494.2006 .00389 . \mathrm{x}$

De Paola, M., \& Gioia, F. (2016). Who performs better under time pressure? Results from a field experiment. Journal of Economic Psychology, 53, 37-53. doi:10.1016/j.joep.2015.12.002

De Young, C. G., Peterson, J. B., \& Higgins, D. M. (2002). Higher-order factors of the Big Five predict conformity: Are there neuroses of health? Personality and Individual Differences, 33, 533-552. doi:10.1016/S01918869(01)00171-4

Eagly, A. H. (1987). Sex differences in social behavior: A social role interpretation. Hillsdale, NJ: Erlbaum.

Flynn, F. J., \& Ames, D. R. (2006). What is good for the goose may not be good for the gender: the benefits of self-monitoring for men and women in task groups and dyadic conflicts. Journal of Applied Psychology, 91, 272-281.doi: 10.1037/0021-9010.91.2.272. 272

Gangestad, S. W., \& Snyder, M. (2000). Self-monitoring: Appraisal and reappraisal. Psychological Bulletin, 126,(4) 530-555. doi: 10.1037//0033-2909.126.4.530

Gerlach, P.; Teodoreacu, K.; Hertweig, R. (2019). The truth about lies: A meta-analysis on dishonest behavior. Psychological Bulletin, 145(1), 1-44. doi: 10.1037/bul0000174

Gilligan, C. (1982). In a different voice: Psychological theory and women's development. Cambridge, MA: Harvard University Press.

Gino, F., \& Galinsky, A. D. (2012). Vicarious dishonesty: When psychological closeness creates distance form one's moral compass. Organizational Behavior and Human Decision Process, 119, 15-26. doi: 10.1016/j.obhdp.2012.03.011

Gino, F., Schweitzer, M. E., Mead, N. L., \& Ariely, D. (2011). Unable to resist temptation: How self-control depletion promotes unethical behavior. Organizational Behavior and Human Decision Process, 115, 191-203. doi: 0.1016/j.obhdp.2011.03.001

Glover, S. H., Bumpus, M. A., Logan, J. E., \& Ciesla, J. R. (1997). Re-examining the influence of individual values on ethical decision making. Journal of Business Ethics, 16, 1319-1329.doi: 10.1023/A:1005758402861

Gneezy, U., \& Rustichini, A. (2000). Pay enough or don't at all. Quarterly Journal of Economics, 115, 791-810. doi: 10.1162/003355300554917

Gürlek, M (2020). Shedding light on the relationships between Machiavellianism, career ambition, and unethical behavior intention. Ethics and behavior, on-line first, 1-22, doi: 10.1080/10508422.2020.1764846 
Hewlin, P. F. (2003). And the award for the best actor goes to ... : Facades of conformity in organizational settings. Academy of Management Review, 28 (4), 633-642. doi: 10.5465/AMR.2003.10899442

Hogue, M., Levashina, J., \& Hang, H. (2013). Will I fake it? The interplay of gender, machiavellianism, and self-monitoring on strategies for honesty in job interviews. Journal of Business Ethics, 117(2), 399-411. doi: 10.1007/s10551-012-1525-x

Jaffe, S. \& Hyde, J. S. (2000). Gender Differences in moral orientation: A meta-analysis. Psychological Bulletin, 126, 703.726, doi: 10.1037//0033-2909.126.5.703

Jang, J.; Yu, K. H. F., \& Huang, C (2019). Service employee's concurrent adaptative and unethical behaviors in complex or non-routine tasks: The effects of customer control and self-monitoring personality. Asia Pacific Journal of Management, 36(1), 245-273. doi: 10.1007/s10490-018-9567-y

Jawahar, I. M. (2001). Attitudes, self-monitoring and appraisal behaviors. Journal of Applied Psychology, 86(5), 875-883. doi: 10.1037/0021-9010.86.5.875

Jones, T .M. (1991). Ethical decision-making by individuals in organizations: An issue-contingent model. Academy of Management Review, 16(2), 366-395. doi: 10.2307/258867

Kamenica, E. (2012). Behavioral economics and psychology of incentives. Annual Review of Economics, 4,13.113.26. doi: 10.1146 /annurev-economics-080511-110909

Kish-Gephart, J. J., Harrison, D. A., \& Treviño, L. K. (2010). Bad apples, bad cases, bad barrels: Meta-analytic evidence about sources of unethical decision at work. Journal of Applied Psychology, 95(1), 1-31. doi: $10.1037 / \mathrm{a} 0017103$

Kowalski, C. M., Rogoza, R., Vernon, P.A., \& Schermer, J. A. (2019). The Dark triad and the self-presentation variables of social desirable responding and self-monitoring. Personality and Individual Differences, 120, 234-237. doi: 10.1016/j.paid.2017.09.007

Krudet, S.; Erdogan, B; Bauer, T. N. (2019). The self-monitoring personality trait at work: An integrative narrative review and future research directions. The Job Annual Review, 40, 193-208. doi: 10.1002/job.2346

Lammers, H. B. (1991). Moderating influence of self-monitoring and gender on responses to humorous advertising. The Journal of Social Psychology, 131, 57-69. doi: 10.1080/00224545.1991.9713824

Lee, M., Pitesa, M., Pilluta, M., Thau, S. (2017). Male immorality: An evolutionary account of sex differences in unethical negotiation behavior. Academy of Mangement Journal, 60(5), 2014-2044. doi: 10.5465/amj.2015.0461

Mazar, N., Amir, O., \& Ariely, D. (2008). The dishonesty of honest people. Journal of Marketing Research, 45, 633-644. doi: 10.1509/jmkr.45.6.633

McCabe, A. C., Ingram, R., Daton-on, M. C. (2006). The Business of Ethics and Gender. Journal of Business Ethics, 64, 101-116. doi: 10.1007/s10551-005-3327-x

McGrath, R. E., Mitchell, M., Kim, B. H., \& Hough, L. (2010). Evidence for response bias as a source of error variance in applied assessment. Psychological Bulletin, 136, 450-470. doi: 10.1037/a0019216

O'Fallon, M. J., \& Butterfield, K. D. (2005). A review of the empirical ethical decision-making literature: 19962003. Journal of Business Ethics, 59(4), 375-413. doi: 10.1007/s10551-005-2929-7

Ogunfowora, B., Bourdage, J. S., \& Nguyen, B. (2013). An exploration of the dishonest side of selfmonitoring: Links to moral disengagement and unethical business decision-making. European Journal of Personality, 27, 532-544. doi: doi.ord Çg/10.1002/per.1931

Oh, I., Charlier, S. D., Mount, M. K., \& Berry, C. M. (2014). The two faces of high self-monitoring: Chameleonic moderating effects of self-monitoring on the relationship between personality traits and counter-productive work behavior. Journal of Organization Behavior, 35(1), 92-111. doi: 10.1002/job.1856

Oh, H., \& Kilduff, M. (2008). The ripple effect of personality on social structure: Self-monitoring origins of network brokerage. Journal of Applied Psychology, 93(5), 1155-1164. doi: 10.1037/0021-9010.93.5.1155

Pinto, J., Leana, C. R., \& Pil, F. K. (2008). Corrupt organizations or organizations of corrupt individuals? Two types of organization-level corruption. Academy of Management Review, 33(3), 685-709. doi: 10.5465/AMR.2008.32465726

Prislin, R., \& Kovrlija, N. (1992). Predicting behavior of high and low self-monitors: An application of the theory of planned behavior. Psychological Reports, 70, 1131-1138. doi: 10.2466/PR0.70.4.1131-1138 
Saquid, N. O., \& Chen, E. Y. (2015). Time Pressure reverses risk preferences. Organization Behavior and Human Decision Process, 130, 56-68. doi: 10.1016/j.obhdp.2015.06.004

Schurchkov, O. (2012). Under pressure: Gender differences in output quality and quantity under competition and time constraint. Journal of The European Economic Association, 10, 1189-1213. doi: 10.1111/j.15424774.2012.01084.x

Shafler, D. R., \& Pegalis, L. J. (1998). Gender and situational context moderate the relationship between selfmonitoring and induction of self-disclosure. Journal of Personality, 16, 215-234. doi: 10.1111/1467-6494.00010. Simons, T. (2002). Behavioral integrity: The perceived alignment between managers' words and deeds as a research focus. Organization Science, 13, 18-35. doi: 10.1287/orsc.13.1.18.543

Snyder, M. (1974). The self-monitoring of expressive behavior. Journal of Personality and Social Psychology, 30 , 526-537. doi: 10.1037/h0037039

Snyder, M. (1987). Public appearances, private realities: The Psychology of self-monitoring. New York: Freeman.

Snyder, M., \& Kendzierski, D. (1982). Choosing social situations: Investigating the origins of correspondence between attitudes and behaviors. Journal of Personality, 50(3), 280-295. doi: 1 0.1111/j.14676494.1982.tb00751.x

Treviño, L. K., Hartman, L. \& Broen, M. (2000). How executives develop a reputation for ethical leadership. California Management Review, 42(4), 128-142. doi: 10.2307/41166057

Türetgen, I. O., Unsal, P., \& Dural, U. (2017). The role of leadership perception as a mediator between manager's self-monitoring and subordinate attitudes. The Journal of Social Psychology, 157(3), 295-307. doi:10.1080/00224545.2016.1192096

Wilmot, M. P., De Young, C. G.; Stillwell, D.; Kosinski, M. (2016). Self-monitoring and the Metatraits”. Journal of Personality, 84(3), 335-347. doi: 10.111/jopy.12162

Wiltermuth, S. S. (2011). Cheating more when the spoils are split. Organizational Behavior and Human Decision Process, 115, 157-168. doi: 10.1016/j.obhdp.2010.10.001

Yang, J., Yu, K. H. F., \& Huang, C. (2019). Service employee's concurrent adaptative and unethical behavior in complex or non-routine tasks: The effects of customer control and self-monitoring personality. Asia Pacific Journal of Management, 36, 245-273. Doi: 10.1007/s10490-018-9567-y 